\title{
Conceptul de securitate criminologică în spaţiul post-sovietic
}

\section{Criminological security concept in post-soviet states}

\author{
Valeriu Bujor $^{1}$, Andrei Claşevici ${ }^{2}$
}

\begin{abstract}
Rezumat:
În prezentul studiu au fost analizate publicaţii ştiinţifice din Republica Moldova şi din ţările spaţiului post-sovietic, unde în mod direct ori tangenţial a fost abordată problema securităţii criminologice. Autorii au avut drept scop elucidarea caracteristicilor esenţiale ale conceptului de securitate criminologică şi, în final, formularea unei definiţii proprii a noţiunii respective. Securitatea criminologică este definită ca starea de protecţie contra pericolului şi ameninţărilor criminale la adresa intereselor legitime ale individului sau colectivităţilor de indivizi, asigurată şi garantată prin mijloace specifice, în cadrul unui sistem de asigurare a securităţii criminologice.
\end{abstract}

Cuvinte-cheie: securitate, securitate criminologică, asigurarea securităţii criminologice, pericole şi ameninţări criminale.

\begin{abstract}
In this study, were analyzed scientific publications in the Republic of Moldova and the post-soviet states, where the problem of criminological security was addressed directly or tangentially. An author's purpose was to elucidate the essential characteristics of the concept of criminological security and, finally, formulating a proprietary definition of the notion. Criminological security is defined as the state of protection against criminal threats and threats to the legitimate interests of individual or individuals' collectivities, ensured and guaranteed by specific means, within a criminological security system.
\end{abstract}

Keywords: security, criminological security, insurance of criminological security, hazards and criminal threats.

\section{Introducere}

În prezent, ca şi în anii de mai înainte, securitatea cetăţenilor, a societăţii şi a statului este ameninţată cel mai grav de criminalitate şi de interesele criminale, deoarece criminalitatea are un puternic impact negativ şi destabilizator asupra tuturor sferelor vieţii sociale şi de activitate ale statului, frânând considerabil

${ }^{1}$ Profesor univ. dr. , Institutul de Științe Penale și Criminologie Aplicată, Chișinău, email: ascrim@rambler.ru.

${ }^{2}$ Doctorand, Universitatea Liberă Internațională din Moldova. 
dezvoltarea social-economică a acestora ${ }^{3}$. Sub acest aspect, cercetătorii au pus în discuţie problema securităţii anticriminale ${ }^{4}$ (sau a securităţii anticrimă $\breve{a}^{5}$ ), dezvoltându-se astfel o adevărată teorie a securităţii criminologice ${ }^{6}$, chiar dacă, conceptul de securitate criminologică este considerat de unii cercetători discutabil ${ }^{7}$. Apariţia acestei teorii criminologice sectoriale constituie nu doar lansarea în circuitul ştiinţific a unui nou concept ştiinţific, dar şi o schimbare radicală, o redirecţionare a politicii anticrimă de la una represivă (de luptă, contracarare) la una preponderent preventivă (de apărare şi anticipare, de protecţie, profilaxie).

Prezentul studiu are drept scop elucidarea caracteristicilor esenţiale ale securităţii criminologice văzute de cercetătorii din spaţiul post sovietic, şi formularea unei definiţii proprii a noţiunii respective. Au fost analizate publicaţii ştiinţifice din Republica Moldova şi din alte ţări ale fostei URSS, unde în mod direct ori tangenţial a fost abordată problema securităţii criminologice.

\section{Puncte de vedere cu privire la conceptul de securitate criminologică}

Pentru prima oară în spaţiul moldovenesc, într-un manual de criminologie Valeriu Bujor şi Octavian $\mathrm{Bejan}^{8}$, au inclus o temă dedicată securităţii

3 М. Бабаев, В. Бужор, $K$ вопросу об обеспечении криминологической безопасности, в Закон и Жизнь, №. 1/2003, с. 8; Б. Бидова, Обеспечение криминологической безопасности России, в Наука и образование: хозяйство и экономика; предпринимательство; право и управление, №. 2(45)/2014, с. 53.

4 А.Г. Горшенков, Г.Г. Горшенков, Г.Н. Горшенков, Информационная преступность: криминологическая безопасность личности, угрозы и меры ее защиты, в Вестник нижегородского университета им. Н.И. Лобачевского, серия: Право, №. 1/2003, сс. 13-16; Г.Г. Горшенков, Антикриминальная безопасность личности. Монография, Нижний Новгород, Издательство Волго-Вятской академии госслужбы, 2006, c. 14.

${ }^{5}$ O. Bejan, Dicționar de criminologie, Ericon SRL, Chișinău, 2009, p. 86.

6 М.М. Бабаев, В.А. Плешаков, Теоретические и прикладные проблемы обеспечения криминологической безопасности, в Уголовная политика и проблемы безопасности государства, Москва, 1998; В.А. Плешаков, Криминологическая безопасность в системе национальной безопасности (опыт структурного анализа), в Криминологический журнал, №. 1/2005, сс. 5-9; В.А. Плешаков, Криминологическая безопасность и ее обеспечение в сфере взаимовлияния организованной преступности и преступности несовершеннолетних, Академия управления МВД России, Москва, 1998; O. Bejan, V. Bujor, Elemente de teoria securităţii criminologice private (material didactic), Institutul de Științe Penale și Criminologie Aplicată, Chișinău, 2014, 98 p. ; O. Bejan, V. Bujor, Bazele asigurării securității criminologice private: material didactic, Institutul de Științe Penale și Criminologie Aplicată, Tipografie „Bora grup”, Chișinău, 2016, 210 p.

7 О.И. Кисиева, К вопросу о понятии криминологической безопасности, в Теоретические и прикладные аспекты современной науки: сборник научных трудов по материалам VIII Международной научно-практической конференции 27 февраля 2015 г., в 7 ч., часть VI, под общ. ред. М.Г. Петровой, Белгород, 2015, с. 58.

${ }^{8}$ V. Bujor, O. Bejan, Curs elementar de criminologie, Institutul de Științe Penale și Criminologie Aplicată, Tipografie „Bora grup”, Chișinău, 2016, 129 p. 
criminologice, aceasta fiind definită ca starea obiectivă în care nimeni nu poate sau nu vatămă în mod criminal interesele legitime ale unei persoane sau ale unui grup de persoane (grup, societate, stat, alianţă de state) ${ }^{9}$. Această definiţie este una generală, destinată studentului pentru o înţelegere generală a noţiunii respective, fiind scoase în evidenţă principalele aspecte - starea în care în mod criminal nu sunt vătămate interesele cuiva. În manual, autorii definesc şi noţiunile de bază ale conceptului de securitate criminologică ${ }^{10}$.

În linii generale, în manualul criminologilor moldoveni, atestăm conceptul securităţii criminologice promovat de criminologul din Federaţia Rusă Mihail Babaev şi discipolii acestuia Vladimir Pleşacov şi Valeriu Bujor ${ }^{11}$.

Principalele teze ale acestuia concept au şi stat la baza formulării propriului concept al securităţii criminologice pe care încercăm să-l formulăm în acest studiu. Criminologii Mihail Babaev, Vladimir Pleşacov şi Valeriu Bujor definesc securitatea criminologică ca starea obiectivă de protecţie a intereselor vitale, şi ale intereselor de altă natură ale persoanei, ale societăţii şi ale statului împotriva atentatelor criminale şi a pericolului acestor atentate, cauzat de diferiţi factori criminogeni (fenomene şi procese), de activitatea criminală şi de interesele criminale. Securitatea criminologică înseamnă şi conştientizarea de către cetăţeni a acestei protecţii contra pericolului criminal sau atentatelor criminale ${ }^{12}$.

Un alt studiu, cu referire la securitatea criminologică îl atestăm la cercetătoarea Irina Iacub care constată, pe bună dreptate, că problema securităţii criminologice, în mod nejustificat nu a fost acceptată până în prezent de

${ }^{9}$ Ibidem, p. 114; V. Bujor, O. Bejan, Bazele asigurării securității criminologice private: material didactic, p. 4.

${ }^{10}$ V. Bujor, O. Bejan, Curs elementar de criminologie, pp. 114-115.

11 М.М. Бабаев, Криминологическая безопасность в системе национальной безопасности (опыт структурного анализа), в Криминологический журнал, № 1/2005, pp. 33 - 41; М.М. Бабаев, В.А. Плешаков, Криминологическая безопасность и ее обеспечение в сбере взаимовлияния организованной преступности и преступности несовершеннолетних, р. 75; М. Бабаев, В. Бужор, $K$ вопросу об обеспечении криминологической безопасности, pp. 6-14; V. Bujor, O. Bejan, Curs elementar de criminologie, p. 6.

${ }^{12}$ M.M. Бабаев, В.А. Плешаков, op. cit., p. 75; М.М. Бабаев, В.Г. Бужор, op. cit., p. 10; В.А. Плешаков, Криминологическая безопасность в системе национальной безопасности (опыт структурного анализа), рp. 5-9; Плешаков В.А. Криминологическая безопасность и система ее обеспечения в современных условия, в Россия в современном мире: проблемы, поиски, решения, Научные труды Института международного права и экономики имени А.С. Грибоедова, Выпуск 2005 г., Москва, 2005, p. 211; V. Bujor, Referințe asupra conceptului de securitate criminologică, în Materialele conferinței științifico-practice internaţionale „Criminalitatea în Republica Moldova: starea actuală, tendințele, măsurile de prevenire și combatere”, 1819 aprilie 2003, p. 94; M. Babaev, V. Bujor, Noțiunea de securitate criminologică, în Revista de criminologie, drept penal și criminalistică, nr. 1-2/2003, p. 15. 
comunitatea ştiinţifică autohtonă (drept dovadă servind lipsa studierii acesteia în literatura de specialitate) $)^{13}$.

Irina Iacub susţine că teoria securităţii criminologice este chemată să creeze fundamentul ştiinţific necesar pentru armonizarea activităţii de ocrotire a ordinii de drept a statului cu interesele cetăţenilor, populaţiei, care în esenţă pretinde la un grad mai sporit de protecţie faţă de atentatele criminale, unde organele de drept trebuie asociate nu cu organe de forţă, represive, ci cu organe de protecţie socială ${ }^{14}$. Anume starea de securitate este sensul şi valoarea supremă a activităţii statului şi societăţii în sfera contracarării criminalităţii, afirmă Irina Iacub, concluzionând că securitatea criminologică în esenţă presupune: în primul rând, starea de protecţie a intereselor vitale ale persoanei, societăţii şi statului faţă de atentatele criminale; în al doilea rând, starea de protecţie faţă de pericolele acestor atentate, generate de diferiţi factori criminogeni; în al treilea rând, conştientizarea de către indivizi a unei asemenea protecţii ${ }^{15}$.

Careva alte studii, cu referire la securitatea criminologică, în Republica Moldova nu am atestat. Şi nici întru-n act normativ din ţară, cu referire la securitate, termenul de securitate criminologică de asemenea nu-l atestăm, fapt ce denotă că teoria securităţii criminologice necesită a fi în continuare promovată şi fundamentată. Considerăm că recunoaşterea şi aplicarea acestei teorii va fi benefică nu doar dezvoltării ştiinţei criminologice, dar şi practicii anticrimă, sub aspectul prevenirii infracţionalităţii. Suntem de acord cu afirmaţ̧ia că, în condiţiile recunoaşterii şi aplicării teoriei securităţii criminologice, contracararea criminalităţii se va transforma într-o activitate desfăşurată de către stat (cu implicarea societăţii) în vederea creării şi menţinerii unui regim de securitate criminologică a populaţiei, regim absolut indispensabil pentru liniştea şi dezvoltarea armonioasă a societăţii ${ }^{16}$. Susţine această idee şi profesorul Gheorghe Costache ${ }^{17}$.

Printre cercetătorii din Federaţia Rusă, cu studii reprezentative în securitatea criminologică, enumerăm cele realizate de Ghenadie Avanesov, Mihail Babaev, Vladimir Pleşacov, Semion Lebedev, Ghenadie Gh. Gorşencov, Ghenadie N. Gorşencov, Dimitrie Simonenco.

În Manualul de Criminologie, editat la Moscova, autori - renumiţii criminologi Ghenadie Avanesov, Serghei Inşancov, Semen Lebedev, în capitolul "Asigurarea criminologică a securităţii naţionale" se referă atât la bazele criminologice a securităţii naţionale, cât şi la noţiunea şi esenţa securităţii criminologice ${ }^{18}$.

${ }^{13}$ I. Iacub, Spre o teorie a securității criminologice, în Legea și viața, nr. 7/2014, p. 38.

${ }^{14}$ Ibidem, p. 40.

${ }^{15}$ Ibidem, p. 41.

${ }^{16}$ Ibidem, p. 42.

17 Gh. Costache, Securitatea persoanei reflectată în concepția internațională a securității umane și strategia securității naționale a Republicii Moldova, în Jurnal Juridic Național: teorie și practică, nr. 3/2018, p. 8.

18 Криминология. Учебник для вузов, научный редактор Г.А. Аванесов, ЮНИТИ, Москва, 2006, р. 470. 
Autorii manualului susţin necesitatea unei teorii criminologice speciale şi dezvoltarea ei continuă - teoria securităţii criminologice, afirmând că problema securităţii criminologice are importanţă teoretică şi practică deosebită pentru realizarea politicii de stat în domeniul controlului asupra criminalităţii, care dă un impuls pentru înnoirea arsenalului de idei în acest domeniu. Aceştia consideră o atare teorie actuală şi progresivă, chemată să fundamenteze o nouă ideologie de contracarare a criminalităţii ${ }^{19}$. Se afirmă că în ierarhizarea formelor de asigurare a securităţii criminologice, pe prim plan trebuie să fie apărarea de sursa (izvorul) pericolului şi doar secundar - influenţa asupra sursei de pericol criminal.

Profesorul Ghenadie Avanesov cu colegii, se expun asupra conţinutului măsurilor de securitate criminologică care trebuie să fie îndreptate în primul rând contra pericolelor asupra persoanei, adică văd persoana ca nucleu al măsurilor de asigurare a securităţii criminologice. Un rol aparte ei acordă prevenirii victimologice ca componentă a securităţii criminologice ${ }^{20}$.

Prezintă interes teza, expusă de criminologi, cu referire la controlul criminalităţii de către lumea criminală, având în vedere criminalitatea organizată şi cea profesională care dezvoltă structuri şi metode de asigurare a propriei securităţi prin metode nejuridice şi de alternativă sistemului oficial de asigurare a ordinii de drept. Plus la aceasta, lumea interlopă face tot posibilul de a slăbi sistemul de asigurare a securităţii şi a ordinii de drept ${ }^{21}$. De asemenea, autorii promovează necesitatea fundamentării criminologice a cadrului normativ ce ţine de securitatea naţională la general, a asigurării criminologice a diferitor forme a securităţii (informaţionale, economice, sociale etc.), dar şi asigurarea economică a securităţii criminologice ${ }^{22}$. Referindu-se la criteriile de apreciere a eficacităţii măsurilor de asigurare a securităţii criminologice, consideră că aprecierea socială trebuie să fie criteriul de bază, deoarece este fundamentat pe resimţirea de către cetăţeni a stării de protecţie de criminalitate ${ }^{23}$. În final criminologii definesc securitatea criminologică ca totalitatea măsurilor de ordin politic, ideologic, economic, social-psihologice, juridice şi de altă natură, elaborate şi realizate de organele competente ale statului, structurile sociale prin care cetăţenii vizează preîntâmpinarea (prevenirea) atentatelor criminale la drepturile şi interesele persoanei, societăţii, statulu ${ }^{24}$.

Un alt criminolog, Ghenadie Gorşencov în lucrarea fundamentală Securitatea anticriminală a persoanei, alături de alte tipuri principale de securitate anticrimă ${ }^{25}$, dezvăluie esenţa securităţii criminologice ${ }^{26}$. Acesta consideră că lanţul: criminalitatea - izvor al pericolului - pericol (ameninţare) - securitate, nu este unul
${ }^{19}$ Ibidem, p. 473.
${ }^{20}$ Ibidem, pp. 477-479.
${ }^{21}$ Ibidem, p. 480.
${ }^{22}$ Ibidem, pp. 483, 487.
${ }^{23}$ Ibidem, p. 485.
${ }^{24}$ Ibidem., p. 473.
${ }^{25}$ Г.Г. Горшенков, Антикриминальная безопасность личности, в Диссертации на соискание ученой степени доктора юридических наук, Ставрополь, 2009, pp. 131-174.
${ }^{26}$ Ibidem, pp. 174-185. 
logic şi propune o altă formula: izvor al pericolului criminal - pericolul criminal securitatea anticriminală ${ }^{27}$. Termenul securitate anticriminală nu vine în contradicţie cu cel de securitate criminologică; primul are în vedere rezultatul activităţii de asigurare a securităţii, al doilea - însăşi activitatea criminologică. În dependenţă de specificul acestor măsuri şi subiecţilor care le realizează, activitatea de asigurare a securităţii (anticriminale) a obiectului va avea caracterul respectiv: penală, penitenciară, antiteror etc. În acest context, se are în vedere activitatea criminologică ce ţine de asigurarea securităţii obiectului sau protecţia de pericol criminal.

Ghenadie Gorşencov, în contextual studiului realizat, formulează noţiunea de securitate criminologică a persoanei ca starea de protecţie a acesteia de pericole criminale, cu luarea în calcul a proprietăţilor persoanei, care permite prevederea pericolelor criminale directe sau indirecte, evitarea şi împotrivirea (contracararea) ameninţărilor, datorită condiţiilor special create pentru aceasta ${ }^{28}$.

Un alt studiu fundamental - Criminalitatea şi societatea, a fost realizat de Sieabşah Şapiev din Republica Cazahstan. Un capitol separat în această lucrare este dedicat securităţii criminologice ${ }^{29}$. Spre deosebire de alţi autori, Şapiev analizează securitatea criminologică prin prisma securităţii naţionale, la nivel de societate. De aceea şi definiţia securităţii criminologice, propusă de cercetător, diferă de cele tradiţionale întâlnite în literatura de specialitate, securitatea criminologică este considerată ca o caracteristică calitativă a funcţionării statului, care reflectă capacitatea acestuia de a asigura şi a apăra prin metode şi forme legitime relaţiile sociale de influenta factorilor distructivi (fenomene şi procese) care ameninţă calitatea socială, fizică şi spirituală a persoanei şi societăţii în ansamblü ${ }^{30}$. Securitatea, consideră Sieabşah Şapiev, se prezintă ca o categorie sistemică care reflectă, după conţinut, trei straturi (niveluri): 1) social-economic, 2) geopolitic, 3) politico-juridic şi organizaţional-juridic.

Pericolul criminal (atentate criminale, procesele criminale şi interesele criminale) este considerat de autor, nu doar ca unul din pericolele la adresa societăţii, ci principalul factor distructiv la adresa securităţii naţionale, ca megaproblemă a funcţionării societăţii şi a civilizaţiei umane. Autorul afirmă că rolul primordial în fundamentarea politicii anticrimă îl constituie consolidarea teoriei securităţii criminologice ${ }^{31}$.

${ }^{27}$ Ibidem, p. 182.

28 Ibidem, p. 183.

${ }^{29}$ С.М. Шапиев, Преступность и общество (криминологическое и теоретикоприкладное исследование), в Диссертации на соискание ученой степени доктора юридических наук, Санкт-Петербург, 2000, 450 р.

${ }^{30}$ Ibidem p. 414.

31 Ibidem p. 416. 
Această teză este împărtăşită şi de criminologul rus Semion Lebedev în articolul Securitatea criminologică în sistemul securităţii naţionale a Rusiei². Este semnificativ, în viziunea noastră, că redacţia jurnalului Росcuйскиŭ криминологический взгляд, a plasat acest articol în rubrica - Victimologie.

Semion Lebedev, sugerează că securitatea, asigurarea şi starea acesteia, sunt acel teren, unde prevenţia statală a infracţionalităţii şi represiunea statală trebuie să se împreuneze armonios, pentru a crea condiţii decente de convieţuire liniştită a oamenilor ${ }^{33}$.

Criminologul împărtăşeşte opinia conform căreia securitatea statului şi societăţii este starea de protecţie a intereselor vitale de pericole interne şi externe şi că securitatea este o caracteristică esenţială a sistemului social şi garanţie a existenţei acestuia, caracterizându-se prin aşa semne sistemice ca: integritate, stabilitate şi independenţă ${ }^{34}$.

Din totalitatea pericolelor la adresa securităţii naţionale, Simion Lebedev evidenţiază criminalitatea şi, de aici, necesitatea includerii în Legea despre securitate a componentei criminologice unde să fie prevăzute aspectele ce ţin de asigurarea socială şi statală a controlului asupra criminalităţii, proceselor şi fenomenelor care o determină; aprecierea în plan juridic a obiectelor şi subiecţilor asigurării securităţii criminologice, sarcinile şi funcţiile acestora, competenţele şi responsabilitatea pentru neasigurarea securităţii statului, societăţii, persoanei ${ }^{35}$.

Într-adevăr, o asemenea reglementare legislativă ar permite crearea bazei juridice a asigurării criminologice a securităţii naţionale. În acest context precizăm că în pofida declaraţiilor, la nivel politic şi al conducătorilor organelor de drept, referitor la prioritatea prevenirii criminalităţii, de facto, prevenţia rămâne în afara reglementării juridice şi fără careva consecinţe pentru responsabilii de realizarea măsurilor preventive în asigurare ordinii de drept şi a securităţii criminologice.

Criminologul Lebedev descrie mecanismele asigurării criminologice a securităţi naţionale: sociale, juridice, economice, informaţionale, administrative ${ }^{36}$ şi domeniile în care se manifestă securitatea criminologică: politic, economic, informaţional, social, ecologic, militar, tehnico-ştiinţific etc. ${ }^{37}$. Deosebit de interesante sunt şi următoarele teze ale criminologului: necesitatea aprecierii criteriilor stării optimale de securitate, necesitatea dezvoltării teoriei şi practicii asigurării criminologice a securităţii naţionale, crearea structurilor (centrului) informaţional-analitice în domeniul securităţii criminologice care ar elabora programe complexe vizând controlul asupra criminalităţii ${ }^{38}$.

32 С.Я. Лебедев, Криминологическая безопасность в системе национальной безопасности России, в журнале Российский криминологический взгляд, № 3/2006, c. $104-110$.

${ }^{33}$ Ibidem, p. 104.

${ }^{34}$ Ibidem.

${ }^{35}$ C.M. Шапиев, op. cit., p. 105.

36 Ibidem, pp. 105-107.

37 Ibidem, pp. 108-109.

38 Ibidem, pp. 109-110. 
Şi cercetătorul Dumitru Simonenco, afirmă că securitatea criminologică este starea obiectivă de protecţie a drepturilor, libertăţilor şi intereselor legitime ale persoanei, societăţii şi statului de atentate infracţionale, pericolul unor asemenea atentate şi conştientizarea de către persoane a stării de protecţie ${ }^{39}$.

Lucrările analizate de noi sunt reprezentative, alte lucrări derivă deja din acestea, de aceea în expunerea noastră ne-am oprit aici. La general, în spaţiul ex-sovietic, securitatea criminologică este definită ca starea de protecţie a intereselor legitime ale persoanei, societăţii şi a statului de pericole externe şi interne, generate de fenomene care într-o măsură sau alta au tangenţe cu criminalitatea, atentate social periculoase, activităţi infracţionale, interese criminale. Atare definiţie, cu unele particularităţi, întâlnim practic la toţi autorii care au abordat problema securităţii criminologice. Aceasta se poate explica prin faptul că definiţiile propuse sunt inspirate din aceleaşi surse din Federaţia Rusă, unde conceptul de securitate criminologică, a şi fost lansat în circuitul criminologic. În acelaşi timp precizăm că în majoritatea studiilor unde este abordată problema securităţii criminologice, ca subiect de discuţii, aceasta este analizată în contextul altor probleme criminologice, cum ar fi criminalitatea organizată, criminalitatea economică, criminalitatea minorilor, migraţia etc.

Analizând şi generalizând mai multe studii de valoare în domeniu, am încercat să formulăm o proprie definiţie a securităţii criminologice, fiind conştienţi de faptul că de înţelegerea noţiunii respective depinde formularea scopului, sarcinilor şi funcţiilor sistemului de asigurare a securităţii criminologice a diferitor obiecte (persoanei, societăţii, statului, organizaţiei).

Securitatea criminologică o definim ca starea de protecţie contra pericolului şi ameninţărilor criminale la adresa intereselor legitime ale individului sau colectivităţilor de indivizi, asigurată şi garantată prin mijloace specifice, în cadrul unui sistem de asigurare a securităţii criminologice.

În continuarea studiului nostru vom aborda şi alte noţiuni care, în ansamblu, constituie conceptul securităţii criminologice.

Obiectul securităţii criminologice, este format din interesele vitale, drepturile şi libertăţile, viaţa şi sănătatea cetăţenilor, proprietatea, instituţiile statale şi sociale, a căror funcţionare asigură prevenirea crimelor şi protecţia contra atentatelor criminale $^{40}$. Referitor la starea obiectivă de protecţie pe care o presupune conceptul de securitate criminologică, atragem atenţia că specialiştii criminologi recunosc că însăşi noţiunea în cauză este una relativă şi nu absolută ${ }^{41}$ (întrucât în realitate nu poate fi asigurată o securitate absolută ${ }^{42}$. În viaţă, ameninţările criminale, riscurile şi pericolele, ca şi manifestările criminale reale, vor exista atât cât va exista şi

39 Д.А. Симоненко, Теория криминологической безопасности и её социологическое обеспечение, в Криминологический журнал, № 9/2006, р. 19.

40 V. Bujor, op. cit., p. 95; М.М. Бабаев, В.Г. Бужор, К вопросу об обеспечении криминологической безопасности, р. 12.

${ }^{41}$ Ibidem, p. 11.

42 O. Bejan, V. Bujor, Bazele asigurării securității criminologice private: (material didactic), p. 4. 
societatea. Iată de ce este greşită părerea că ar putea exista o stare de securitate în care să lipsească, cu desăvârşire, conduite antisociale şi criminale. O asemenea stare practic este de neatins ${ }^{43}$. Altfel spus, starea de securitate poate fi apreciată ca un nivel zero de survenire a pericolului sau ameninţării doar ipotetic, însă sub aspect practic (real) starea absolută de securitate, fiind imposibilăa ${ }^{44}$ Din considerentele date, specialiştii propun a reflecta asupra parametrilor acestor pericole, asupra condiţiilor care le-ar reduce la un nivel minim posibil, condiţii în care starea şi dinamica criminalităţii să reacţioneze prompt şi adecvat la eforturile anticriminogene ale societăţii şi statului ${ }^{45}$. Prin urmare, starea securităţii criminologice, nefiind una absolută, ar putea fi apreciată în funcţie de grad şi probabilitate (de exemplu: foarte mare, mare, medie, mică şi foarte mică) ${ }^{46}$, iar scopul asigurării acesteia ar consta în crearea şi menţinerea unui nivel socialmente acceptabil şi maximum posibil de securitate criminologică în condiţii social-istorice concrete ${ }^{47}$.

Referindu-ne la pericolele ce ameninţă securitatea criminologică (şi care de altfel îi determină esenţa şi natura), trebuie precizat că din categoria acestora fac parte, în primul rând, criminalitatea sub toate formele sale (ex.: criminalitatea economică, criminalitatea contra proprietăţii, criminalitatea organizată, criminalitatea tenebră, criminalitatea informatică, corupţia etc.), ansamblul de cauze şi condiţii ce determină criminalitatea şi care creează un pericol criminal real sau potenţial la adresa obiectelor securităţii criminologice; or, altfel spus, totalitatea factorilor criminogeni care pun în pericol interesele vitale ale persoanei, societăţii şi statului ${ }^{48}$. În esenţă, pericolele şi ameninţările criminale constituie factori care pot să distrugă sau care distrug, parţial sau totalmente, obiectul securităţii criminologice ${ }^{49}$.

O altă noţiune - asigurarea securităţii criminologice, în studiile de specialitate aceasta este definită ca activitatea statului, a societăţii şi a instituţiilor acestora bazată pe principiile programării şi planificării complexe, având scopul să atingă un asemenea nivel de protecţie a intereselor vitale şi esenţiale ale persoanei, societăţii şi statului, care să corespundă criteriilor de bază ale securităţii criminologice posibilă în anumite condiţii istorice ${ }^{50}$. Activitatea de asigurare a

${ }^{43}$ V. Bujor, Referințe asupra conceptului de securitate criminologică, p. 94.

${ }^{44}$ Б. Бидова, op. cit., p. 53.

${ }^{45}$ V. Bujor, Referințe asupra conceptului de securitate criminologică, p. 94.

46 O. Bejan, V. Bujor, Bazele asigurării securității criminologice private (material didactic), p. 4.

47 М.М. Бабаев, В.Г. Бужор, K вопросу об обеспечении криминологической безопасности, p. 12; V. Bujor, A. Clașevici, Unele aspecte ale concepției de securitate criminologică a întreprinderii, în Conceptul de dezvoltare a statului de drept în Moldova și Ucraina în contextul proceselor de eurointegrare, Conferința internațională științificopractică, Chișinău, Republica Moldova, 4-5 noiembrie 2016, p. 198.

48 O. Bejan, V. Bujor, Bazele asigurării securității criminologice private (material didactic), p. 95; М.М. Бабаев, В.Г. Бужор, К вопросу об обеспечении криминологической безопасности, p. 12.

49 O. Bejan, V. Bujor, Bazele asigurării securității criminologice private (material didactic), op. cit., p. 9.

50 Ibidem, p. 94. 
securităţii criminologice include în sine totalitatea măsurilor economice, politice, juridice, organizaţionale şi de altă natură orientate $\operatorname{spre}^{51}$ : apărarea drepturilor constituţionale, a libertăţilor, inviolabilităţii persoanei şi a proprietăţii acesteia împotriva atentatelor criminale; asigurarea eficacităţii sistemului de prevenire a criminalităţii; prevenirea ameninţărilor şi riscurilor criminale la adresa stării socialmente acceptabile de securitate criminologică; reacţia adecvată la apariţia ameninţărilor criminale şi la modificarea stării socialmente acceptabile de securitate criminologică; lichidarea şi minimalizarea consecinţelor atentatelor criminale.

În cele din urmă, complexitatea activităţii de asigurare a securităţii criminologice determină conturarea unui adevărat sistem de asigurare a securităţii criminologice prin care înţelegem totalitatea subiecţilor, măsurilor politice, juridice, organizaţionale, economice, ştiinţifice etc., orientate spre menţinerea unui nivel de securitate criminologică socialmente acceptabil; asigurarea financiară, cu resurse tehnice, materiale şi de altă natură a acestor măsuri ${ }^{52}$. Or, altfel spus, sistemul securităţii criminologice cuprinde totalitatea subiecţilor, măsurilor şi mijloacelor utilizate în activitatea de asigurare a acesteia.

În acelaşi timp, doctrina identifică şi o serie de funcţii proprii sistemului de asigurare a securităţii criminologice, care constau $\mathrm{in}^{53}$ : elaborarea strategiei de asigurare a securităţii criminologice, asigurarea juridică, financiară, materială etc. a activităţii structurilor de stat, obşteşti şi particulare a cetăţenilor implicaţi în realizarea acesteia; elucidarea, evaluarea, eliminarea sau neutralizarea surselor ameninţărilor criminale faţă de obiectele securităţii criminologice şi controlul operativ-profilactic al stării acestora; evaluarea stării securităţii criminologice în ţară, prognozarea tendinţelor de dezvoltare a acesteia, informarea autorităţilor, a structurilor statale, opiniei publice şi populaţiei referitor la situaţia din domeniu; elaborarea şi asigurarea programelor complexe de asigurare a securităţii criminologice; crearea, dezvoltarea, dotarea, instruirea şi menţinerea în stare de eficienţă a forţelor şi mijloacelor pentru subiecţii asigurării securităţii criminologice; protecţia persoanei şi a patrimoniului, a drepturilor, libertăţilor şi intereselor legitime ale persoanei, asigurarea unei activităţi eficiente a subiecţilor implicaţi în activităţi de prevenire a criminalităţii şi atragerea la răspundere a persoanelor vinovate de comiterea infracţiunilor contra obiectelor protecţiei criminologice; crearea în societate a premiselor moral-psihologice necesare pentru asigurarea securităţii criminologice, cu implicarea păturilor largi ale populaţiei.

Dincolo de cele expuse, o atenţie distinctă merită subiecţii care asigură securitatea criminologică. În funcţie de subiecţii care asigură securitatea

51 М.М. Бабаев, В.Г. Бужор, $K$ вопросу об обеспечении криминологической безопасности, р. 13.

${ }^{52} \mathrm{~V}$. Bujor, Referințe asupra conceptului de securitate criminologică, p. 9; М.М. Бабаев, B.Г. Бужор, К вопросу об обеспечении криминологической безопасности, р. 12.

53 М. Бабаев, В. Бужор, $K$ вопросу об обеспечении криминологической безопасности, р. 13. 
criminologică, în literatura de specialitate se trasează o delimitare clară între securitatea publică şi cea privată ${ }^{54}$.

\section{Concluzii}

Generalizând asupra subiectului abordat, constatăm că securitatea criminologică este caracterizată prin următoarele semne definitorii:

- este starea sistemului social, care constă în capacitatea şi posibilitatea acestuia de a preveni şi a se apăra eficient de pericole şi ameninţări criminale şi de a înlătura consecinţele negative;

- este o stare obiectivă de protecţie, dar şi subiectivă întrucât, presupune şi conştientizarea de către cetăţeni a siguranţei faţă de pericolul criminal (argument important invocat întru susţinerea implementării securităţii criminologice în politica penală ${ }^{55}$;

- obiectul securităţii criminologice îl constituie drepturile şi libertăţile persoanei, interesele legitime ale persoanei, interesele vitale ale societăţii şi ale statului, de asemenea, sistemul de relaţii sociale chemat să garanteze realizarea acestor interese;

- interesele ca valori sociale (libertatea, viaţa, patrimoniul, libera activitate de antreprenoriat, suveranitatea etc.) sunt protejate împotriva pericolului şi ameninţărilor criminale (trăsătură ce în viziunea noastră permite delimitarea securităţii criminologice de alte dimensiuni ale securităţii);

- starea de protecţie a obiectului şi siguranţa acestuia se realizează prin mijloace specifice (preventive şi represive) de către subiecţii sistemului de asigurare a securităţii criminologice (încă un argument în evidenţierea securităţii criminologice ca formă distinctă a securităţii);

- asigurarea securităţii criminologice a persoanei, societăţii, statului trebuie să fie realizată în baza unui cadru juridic adecvat, fundamentat pe politica naţională în domeniul anticrimă (politica criminologică şi politica penală).

\section{Referinţe}

Babaev M., Bujor V., Noţiunea de securitate criminologică, în Revista de criminologie, drept penal şi criminalistică, nr. 1-2/2003, pp. 14-19.

Bejan O., Dicţionar de Criminologie, Ericon SRL, Chişinău, 2009, 104 p.

Bejan O., Bujor V., Bazele asigurării securităţii criminologice private (material didactic), Institutul de Ştiinţe Penale şi Criminologie Aplicată, Tipografia „Bora grup”, Chişinău, 2016, 210 p.

Bejan O., Bujor V., Elemente de teoria securităţii criminologice private (material didactic), Institutul de Ştiinţe Penale şi Criminologie Aplicată, Chişinău, 2014, 98 p.

Beşleagă Gr., Guţuleac V., Asigurarea securităţii publice în timpul tulburărilor şi dezordinilor de masa, Academia de Poliţie „Ştefan cel Mare”, Chişinău, 1998, 183 p. didactic), p. 5.

${ }^{54}$ O. Bejan, V. Bujor, Elemente de teoria securității criminologice private (material

${ }^{55}$ I. Iacub, Spre o teorie a securității criminologice, pp. 38-42. 
Bujor V., Referinţe asupra conceptului de securitate criminologică, în „Criminalitatea în Republica Moldova: starea actuală, tendinţele, măsurile de prevenire şi combatere”. Materialele conferinţei ştiinţifico-practice internaţionale, 18-19 aprilie 2003, p. 94.

Bujor V., Claşevici A., Unele aspecte ale concepţiei de securitate criminologică a întreprinderii, în Conceptul de dezvoltare a statului de drept în Moldova şi Ucraina în contextul proceselor de euro-integrare. Conferinţa internaţională ştiinţifico-practică, Chişinău, Republica Moldova, 4-5 noiembrie 2016, pp. 197-200.

Bujor V., Bejan O., Curs elementar de criminologie, Institutul de Ştiinţe Penale şi Criminologie Aplicată, Tipografia „Bora grup”, Chişinău, 2016, 129 p.

Costache Gh., Securitatea persoanei reflectată în concepția internaţională a securităţii umane şi strategia securităţii naţionale a Republicii Moldova, în Jurnal Juridic Naţional: Teorie şi practică, nr. 3/2018, pp. 4-9.

Cuşnir V., Conceptul securităţii publice, în Poliţia şi securitatea publică, materialele conferinţei ştiinţifico-practice din 9 decembrie 2002. Chişinău, Academia „Ştefan cel Mare", 2003, pp. 14-16.

Iacub I., Spre o teorie a securităţii criminologice, în Legea şi viaţa, nr. 7/2014, pp. 38-42.

Zavatin V., Securitatea publică: perspective legislative, în Poliţia şi securitatea publică, materialele conferinţei ştiinţifico-practice din 9 decembrie 2002, , Academia „Ştefan cel Mare”, Chişinău, 2003, pp. 17-19.

Горшенков А.Г., Горшенков Г.Г., Горшенков Г.Н., Информационная преступность: криминологическая безопасность личности, угрозы и меры ее защиты, в Вестник нижегородского университета им. Н.И. Лобачевского, Серия: Право, № 1/2003, pp. 13-16.

Бидова Б., Обеспечение криминологической безопасности России, в Наука и образование: хозяйство и экономика; предпринимательство; право и управление, № 2(45)/2014, pp. 51-55.

Плешаков В.А., Криминологическая безопасность в системе национальной безопасности (опыт структурного анализа), в Криминологический журнал, № $1 / 2005$, pp. 5-9.

Плешаков В.А., Криминологическая безопасность и ее обеспечение в сфере взаимовлияния организованной преступности и преступности несовершеннолетних. Академия управления МВД России, Москва, 1998, 398 р.

Плешаков В.А., Криминологическая безопасность и система ее обеспечения в современных условиях, в Россия в современном мире: проблемы, поиски, решения, Научные труды ИМПЭ им. А.С. Грибоедова, Выпуск 2005 г., Институт международного права и экономики имени А.С. Грибоедова, Москва, 2005, р. 211.

Горшенков Г.Г., Антикриминальная безопасность личности, в диссертации на соискание ученой степени доктора юридических наук, Ставрополь, 2009, 447 p.

Горшенков Г.Г., Антикриминальная безопасность личности. Монография, Издательство Волго-Вятской академии госслужбы, Нижний Новгород, 2006, 294 р.

Симоненко Д.А., Теория криминологической безопасности и её социологическое обеспечение, в Криминологический журнал, № 9/2006, р. 88 -93.

Горшнева И.А., Полиция в механизме современного демократического государства, Юнинти-Дана, Закон и Право, Москва, 2004, 174 р.

Криминология. Учебник для вузов, Научный редактор Аванесов Г.А., ЮНИТИ, Москва, 2006, $495 \mathrm{p}$.

Бабаев М.М., Бужор В.Г., К вопросу об обеспечении криминологической безопасности, в Закон и Жизнь, № 1/2003, p. 8. 
Бабаев М.М., Криминологическая безопасность в системе национальной безопасности (опыт структурного анализа), в Криминологический журнал, № 1/2005, p. 23 -34 .

Бабаев М.М., Плешаков В.А., Теоретические и прикладные проблемы обеспечения криминологической безопасности, в Уголовная политика и проблемы безопасности государства, Москва, 1998, pр. 29 - 37.

Кисиева О.И., К вопросу о понятии криминологической безопасности, в Теоретические и прикладные аспекты современной науки, сборник научных трудов по материалам VIII Международной научно-практической конференции 27 февраля 2015 г., в 7 ч., часть VI, под общ. ред. М.Г. Петровой, Белгород, 2015, pp. 56-59.

Шапиев С.М., Преступность и общество (криминологическое и теоретико-прикладное исследование), в диссертации на соискание ученой степени доктора юридических наук, Санкт-Петербург, 2000, 450 р.

Лебедев С.Я., Криминологическая безопасность в системе национальной безопасности России, в журнале Российский криминологический взгляд, № 3/2006, pр. 104-110.

Губарева Т.И., Криминологическая безопасность в системе национальной безопасности. Российской Федерации: к постановке проблемы, в Общество и Право, № 3 (40)/2012, pp. 172-174. 